\title{
Chapter 5 Mechanical characterization of the L4 and L5 lumbar vertebrae
}

\section{Capítulo 5 Caracterización mecánica de las vértebras lumbares L4 y L5}

VILLAGRÁN-VILLEGAS, Luz Yazmin ${ }^{1} \dagger^{*}$, SIORDIA-VÁSQUEZ, Xóchitl ${ }^{2}$, CUÉLLAR-OROZCO, Maricela $^{2}$ and PATIÑO-ORTIZ, Miguel ${ }^{1}$

${ }^{1}$ Instituto Politécnico Nacional. Unidad Profesional “Adolfo López Mateos”- Zacatenco, Gustavo A. Madero, Mexico D.F.

${ }^{2}$ Universidad Veracruzana. Faculty of Engineering and Chemical Sciences "Campus Poza RicaTuxpan”- Av. Venustiano Carranza s/n Col. Revolución, Poza Rica, Ver. Ph: +52 7828238143

ID $1^{\mathrm{er}}$ Author: Luz Yazmin, Villagrán-Villegas / ORC ID: 0000-0003-3860-2923, CVU CONACYT ID: 96365

ID $1{ }^{\text {er }}$ Co-author: Xóchitl, Siordia-Vásquez / ORC ID: 0002-8472-8001, CVU CONACYT ID: 1036998

ID $2^{\text {do }}$ Co-author: Maricela, Cuéllar-Orozco / ORC ID: 0000-0002-6558-4938, CVU CONACYT ID: 662076

ID $3{ }^{\text {er }}$ Co-author: Miguel, Patiño-Ortiz / ORC ID: 0000-0002-5630-8077, CVU CONACYT ID: 167388

DOI: $10.35429 / \mathrm{H} .2021 .6 .75 .85$

L. Villagrán, X. Siordia, M. Cuéllar and M. Patiño

*yvillagran@uv.mx

A. Marroquín, J. Olivares, M. Ramírez and L. Cruz (Coord) Engineering and Technology. Handbooks-@ECORFAN-México, Querétaro, 2021. 


\section{Abstract (Mechanical characterization of the lumbar vertebrae)}

Compression fractures in the lumbar region are usually caused by excessive pressure at the level of the vertebral body. The fracture occurs when the vertebral body is crushed, causing the anterior part of the vertebral body to acquire a wedge shape. Bone tissue inside the vertebral body is crushed or compressed. Compression fractures due to trauma may be due to a fall, a strong jump, a car accident, or any other event that emphasizes the spine beyond its breaking point [1]. In a simulation of the fracture in recent studies, loads are applied to real vertebral samples (destructive tests), where both compression loads are fixed on the upper and lower faces of the vertebral body. The literature mentions tests with loads of approximately $8000 \mathrm{~N}$ emulating a daily accident, so this research aims to obtain a precise model with the use of an optical scanner, which will allow the obtaining of points (meshing) of the piece in real time with an individual measurement of up to 16 million independent measurement points captured from 1 to 2 seconds. The measurement data is characterized by a very detailed reproduction and therefore also allows the measurement of sample components up to $38 \mathrm{~mm}$. The following study will begin with the acquisition of plaster and aluminum models, for the different types of samples mentioned below:

- $\quad$ Swine lumbar vertebral simple.

- $\quad$ Human lumbar vertebral simple 4.

- Human lumbar vertebral simple 5.

With the help of the ATOS\&GOM® optical scanner, point clouds were acquired from each of the samples that were used to acquire 3D printing models and obtain 3D solid digital models to perform the Von-Mises stress analysis. As a result of the Von-Mises stress analysis process, when applying compressive loads of $960 \mathrm{~N}$ and shear of $8000 \mathrm{~N}$ distributed in each lumbar vertebra, a maximum Von Mises effort of 134.82 MPa Max and 6.203e-10 MPa Min was obtained for lumbar vertebra 4, 189.6 MPa Max and 2.0437e-9 for lumbar vertebra 5 and 101.2 MPa Max and 0 Min for porcine lumbar vertebra. Critical points are above $100 \mathrm{MPa}$ for all three cases. The maximum values of effort in the vertebral body and the minimum in the spinous process were presented.

\section{Lumbar, Compression fracture, Point cloud, Model acquisition, Von-Mises analysis}

\section{Resumen}

Las fracturas por compresión en la región lumbar, por lo general, se producen por la presión excesiva a nivel del cuerpo vertebral. La fractura se produce cuando se aplasta el cuerpo vertebral, causando que la parte anterior del cuerpo vertebral adquiera forma de cuña. El tejido óseo en el interior del cuerpo vertebral es aplastado, o se comprime. Las fracturas por compresión debido a un traumatismo pueden deberse a una caída, un salto, un accidente de coche, o cualquier otro evento que produce un impacto en la columna vertebral más allá de su punto de ruptura [1]. En una simulación de la fractura en estudios recientes se aplican cargas a muestra vertebrales reales (pruebas destructivas), en donde ambas cargas a compresión se fijan en las caras superior e inferior del cuerpo vertebral. La literatura menciona ensayos con cargas de aproximadamente $8000 \mathrm{~N}$ emulando un accidente cotidiano, por lo que esta investigación pretende obtener un modelo preciso con el empleo de un scanner óptico; el cual permitirá la obtención de puntos (mallado) de la pieza en tiempo real con una medición individual de hasta 16 millones de puntos de medición independientes capturados de 1 a 2 segundos. Los datos de medición se caracterizan por una reproducción muy detallada y por lo tanto también permiten la medición de componentes muestras de hasta de $38 \mathrm{~mm}$. El estudio inicia con la adquisición de modelos en yeso y aluminio de vertebras con similitudes geométricas:

\section{- Muestra vertebral lumbar porcina \\ - Muestra vertebral lumbar humana 4. \\ - $\quad$ Muestra vertebral lumbar humana 5.}

El escáner óptico ATOS\&GOM® adquirió nubes de puntos de cada de una de las muestras mencionadas para el diseño de modelos con impresión 3D y la obtención de modelos digitales sólidos $3 \mathrm{D}$, con la finalidad de realizar el análisis de esfuerzos de Von-Mises; como resultado del proceso de análisis de esfuerzos de Von-Mises, al aplicar cargas a compresión de $960 \mathrm{~N}$ y cortante de $8000 \mathrm{~N}$ distribuidas en cada vértebra lumbar. 
El esfuerzo máximo de Von Mises obtenido fue de 134.82 MPa Max y 6.203e-10 MPa Min para la vértebra lumbar 4, 189.6 MPa Max y 2.0437e-9 para la vértebra lumbar 5 y $101.2 \mathrm{MPa}$ Max y 0 Min para la vértebra lumbar porcina. Los puntos críticos son arriba de los $100 \mathrm{MPa}$ para los tres casos. La simulación presenta los valores máximos de esfuerzo en el cuerpo vertebral y los mínimos en la apófisis espinosa.

Lumbar, Fractura por compresión, Nube de puntos, adquisición de modelos, Análisis de VonMises

\section{Introduction}

The present research work intends to make a mechanical characterization of the L4 and L5 lumbar vertebrae, by means of the use of the ATOS\&GOM $®$ optical scanner, since at present $3 \mathrm{D}$ models have not been worked with high resolution as the one provided by the mentioned scanner. The selection of the L4 and L5 lumbar vertebrae is due to the fact that the lumbar region is prone to suffer some type of injury, as shown in Figure 5.1, since this region is the one that supports the weight of all the body elements added to them.

Figure 5.1 Compression fracture

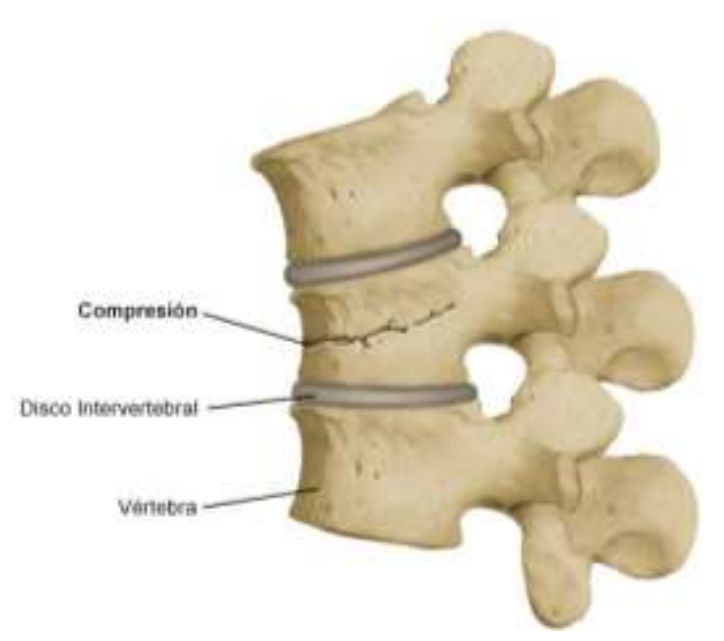

For a better understanding of the clinical problems of the spine and its function, the application of the mechanical theory is indispensable. In this sense, this work focuses on the lumbar region of the human being. The main objective of this research is to perform a Von-Mises stress analysis in ANSYS® Release 18.0 software on vertebral specimens, simulating the stress caused in a vertebral compression fracture.

\section{Development}

The methodology used to carry out this study can be described as follows:

Figure 5.2 Methodology for stress analysis in lumbar L4 and L5

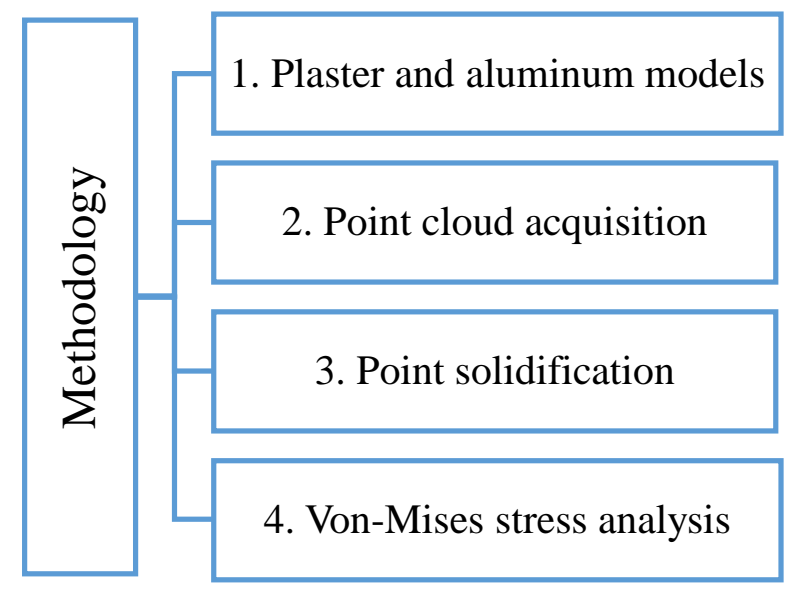




\subsection{Plaster and aluminum models}

The acquisition of the plaster and aluminum models was for the samples of human lumbar vertebrae 4 and 5. Initially, bipartite molds were obtained with the help of dental alginate, which is a gelling agent that allows obtaining impressions; two impressions were made in each vertebral sample, the first one on the upper faces and the second one on the lower faces. (Figure 5.3).

Figure 5.3 Bipartite mold

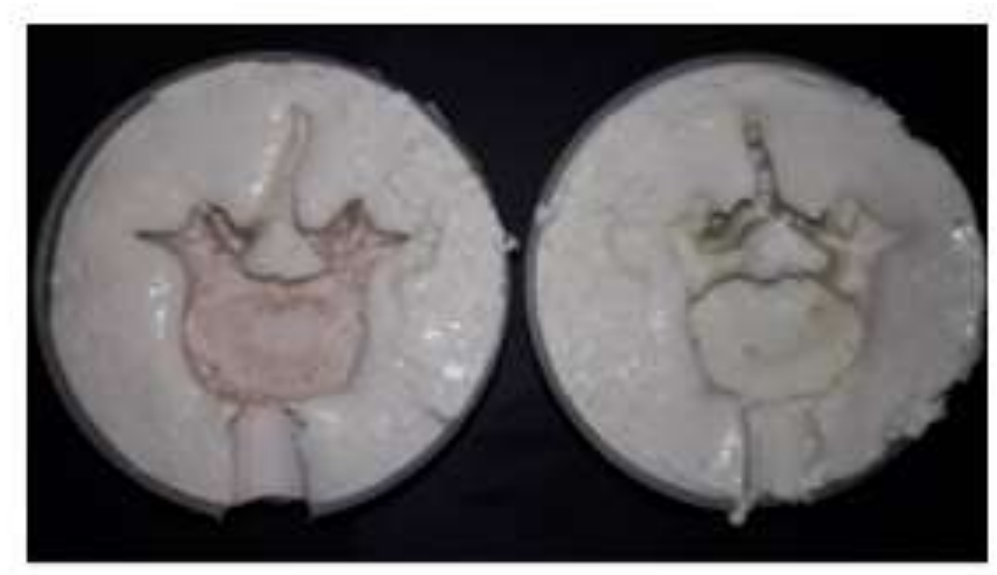

When the bipartite molds were obtained, Type IV high resistance dental plaster with a compressive strength of $510 \mathrm{~kg} / \mathrm{cm} 2$ was poured into them to obtain the plaster models. With the help of a micromotor and a pink stone bur, special for polishing and conical cutting, the excess material generated during the casting was removed (Figure 5.4).

Figure 5.4 Plaster model of L4 vertebra

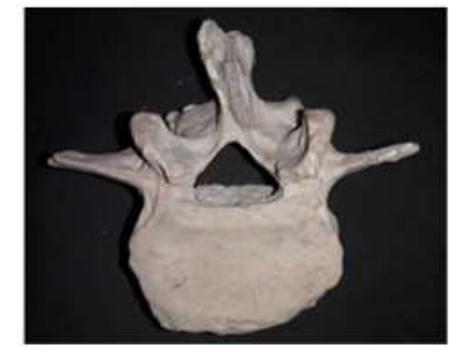

A) Vista superior

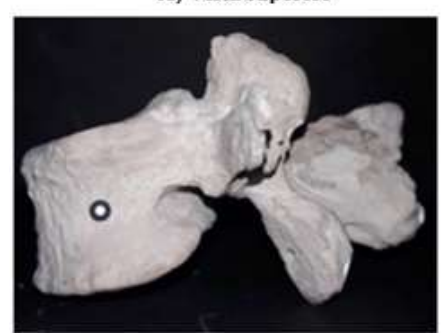

C) Vista lateral derecha

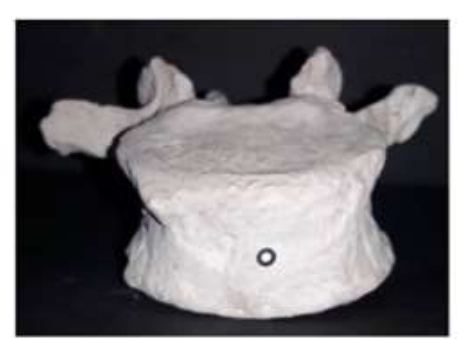

B) Vista anterior

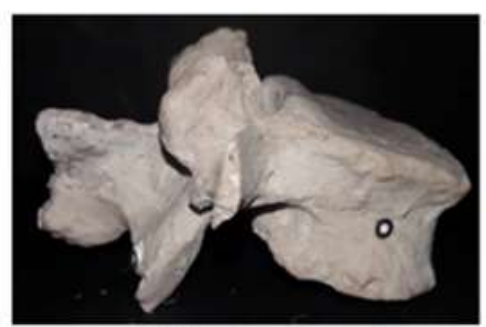

D) Vista lateral izquierda

Taking advantage of the bipartite molds in alginate, kerosene wax was poured in them to obtain replicas of the vertebrae shown in Figure 5.5, which allowed acquiring new plaster molds, with the technique known as "lost wax", which were used to receive the molten aluminum. (Figure 5.5) 
Figure 5.5 Wax replicas of the vertebrae.

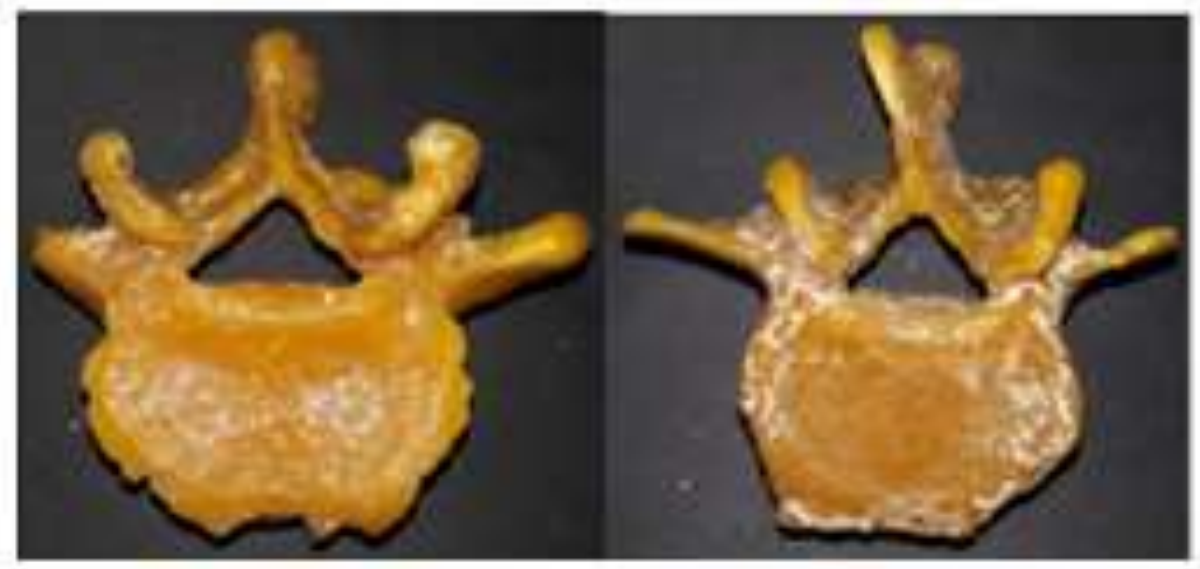

Figure 5.6 Plaster model with the lost wax technique.

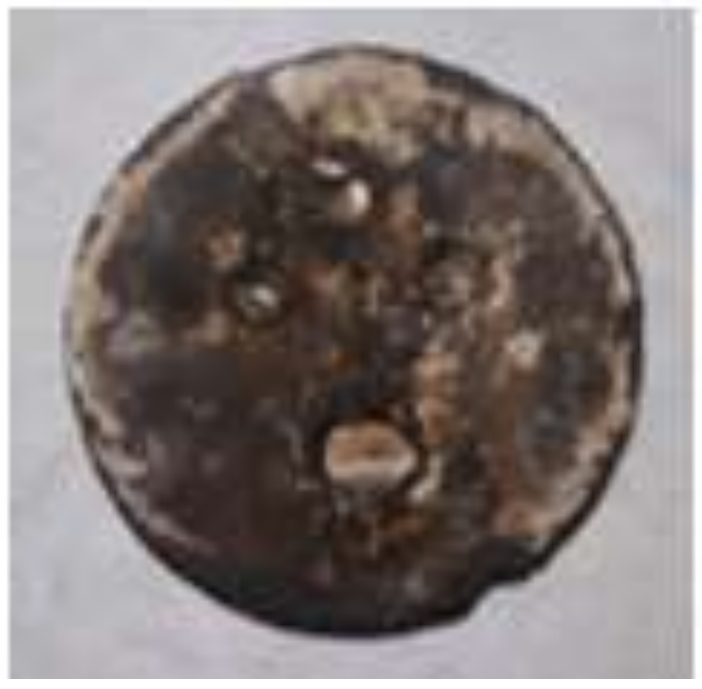

Subsequently, with the help of a smelting furnace, using LP gas and charcoal as fuel and adding a preheated air source, the furnace heating process was carried out, reaching temperatures over $660.3{ }^{\circ} \mathrm{C}$, which allowed the aluminum to be melted. When the aluminum was in a liquid state, it was poured by gravity into the plaster molds; after cooling, and with a manipulable temperature, they were demolded, sacrificing the plaster models and removing the excess generated by the casting with the help of a bench grinder and the micromotor with a metal milling cutter (Figure 5.7).

Figure 5.7 Aluminum model of the L4 vertebrae

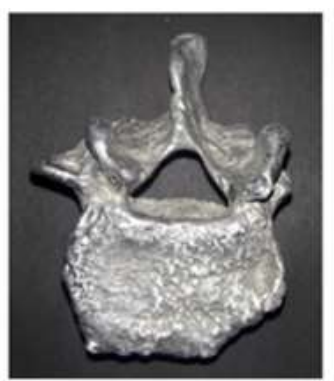

A) Vista superior

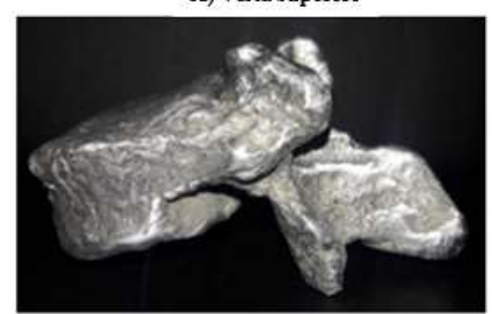

C) Vista lateral derecha

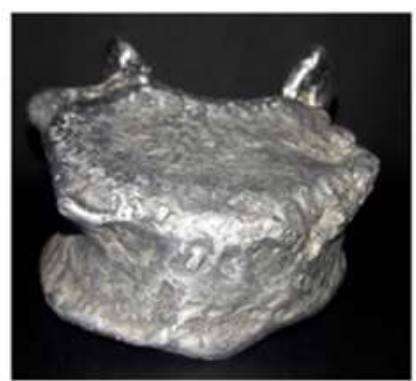

B) Vista anterior

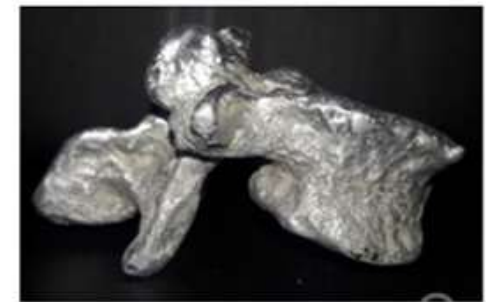

D) Vista lateral izquierda 


\subsection{Point cloud acquisition}

Comparing the plaster and aluminum models of the human lumbar vertebrae, it was decided to use the plaster models for scanning, since they were the ones that had the greatest similarity with the original samples. For the scanning process, it is required that the samples be of a white and opaque color, so that they can be detected by the ATOS\&GOM ${ }^{\circledR}$ optical scanner. It was not possible to scan the original samples due to the characteristics they showed and it was not possible to apply any type of coating on them in order not to damage them, since they were on loan. Particularly the plaster models were detected by the optical scanner without the need to apply any coating.

On the other hand, to scan the porcine lumbar vertebra, since it was an own acquisition, it went through a dissection process and a coating of zinc oxide diluted in alcohol was applied with the help of an airbrush so that the optical scanner could detect the sample.

Once the samples to be used were defined and prepared, they were scanned, having an advanced calibration for the scanner, in order to have greater precision. Different shots of the samples were acquired: lateral and frontal, taking as reference the stickers previously placed on them; this allowed the scanner to have references, since for each of the samples scans were made to the top and bottom, with the mentioned points, allowing the software to join both scans to convert them into a single piece. (Figure 5.8)

Figure 5.8 Scanning process

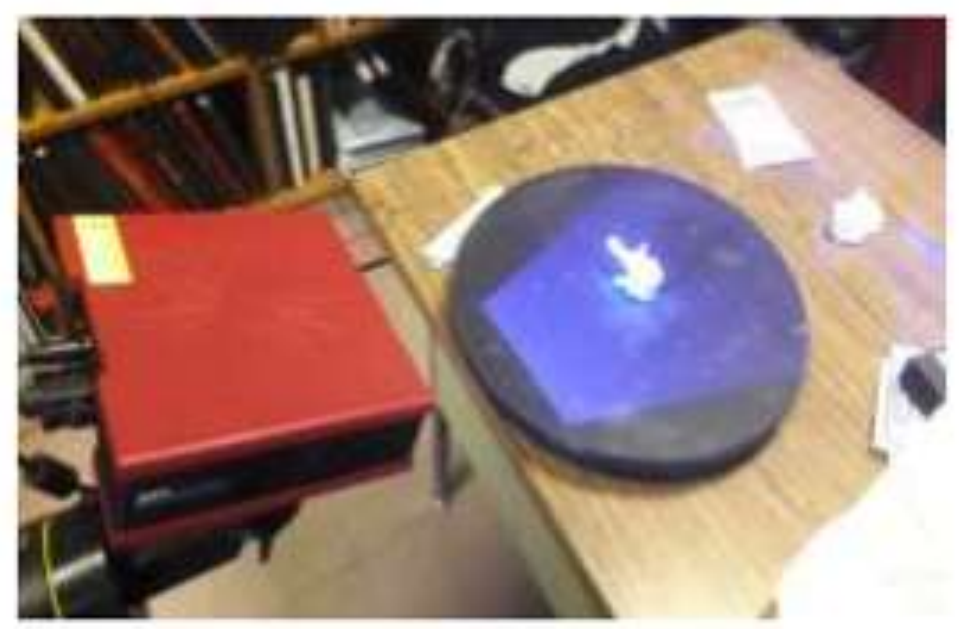

As a result, the point clouds of the vertebral specimens were obtained in STL format, as shown in Table 5.1.

Table 5.1 Number of points in vertebral specimens

\begin{tabular}{|l|l|}
\hline \multicolumn{1}{|c|}{ Sample } & No. of points \\
\hline Porcine lumbar vertebrae & 372498 \\
\hline Human lumbar vertebrae 4 & 531324 \\
\hline Human lumbar vertebrae 5 & 399298 \\
\hline
\end{tabular}

\subsection{Point cloud solidification}

In order to carry out the numerical analysis, the lumbar vertebral samples in 3D must be solidified, so with the help of the CREO PARAMETRIC 5.0® software the point cloud in STL format was converted into a solid 3D drawing in SAT format.

The quality used for the solid drawings of the vertebral specimens required by the software can vary from Level 1 to 10; for the vertebral specimens it was Level 10, since this level is the highest in drawing definition, which helped the numerical analysis to be closer and more accurate to the geometries of the original specimens. (Figure 5.9) 
Figure 5.9 Solidified human vertebral specimen

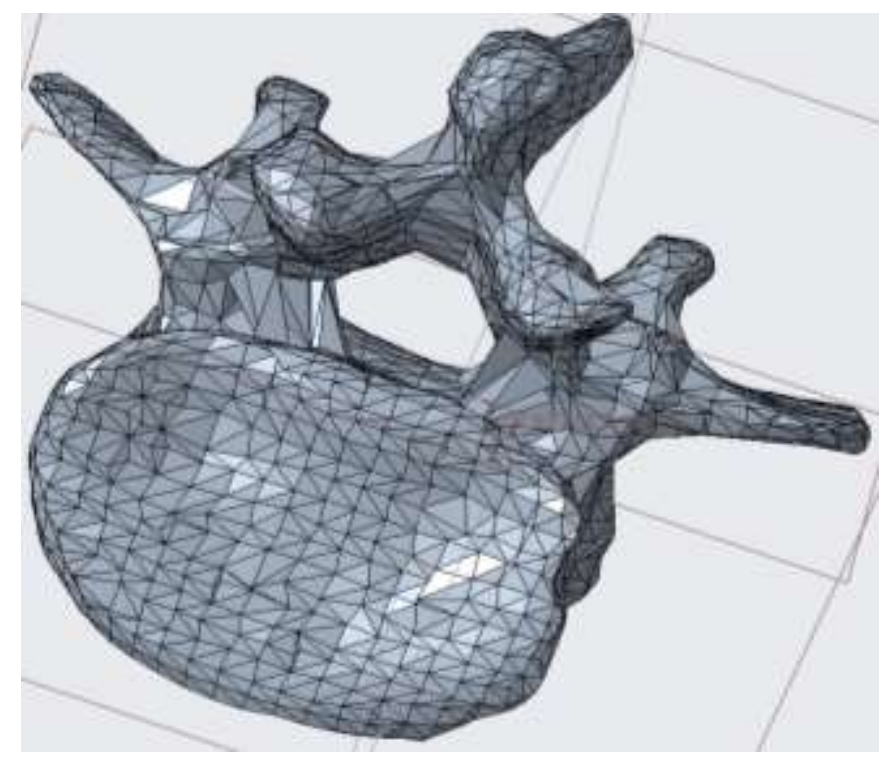

4.4 Von-Mises stress analysis

ANSYS ${ }^{\circledR}$ Workbench ${ }^{\mathrm{TM}}$ Release 18.0 software was used to perform the stress analysis, the solidified specimens were imported into CREO PARAMETRIC 5.0® to work on them. The following data were used to establish the properties of human and porcine lumbar bone.

Table 5.2 Material properties

\begin{tabular}{|l|c|c|c|c|}
\hline & & & \\
\hline Porcine lumbar bone & 229 & 0.3 & 0.14 [3] & $\begin{array}{l}\text { [2] J. Teo, 2006 } \\
\text { [3] T. Keavy, 1997 }\end{array}$ \\
\hline Human lumbar bone & 100 & 0.2 & 0.14 [3] & $\begin{array}{l}\text { [4] J. Wang, 2000 } \\
\text { [3] T. Keavy, 1997 }\end{array}$ \\
\hline
\end{tabular}

To perform the meshing process of the vertebral samples, all the small faces that by default had the solid samples obtained from CREO PARAMETRIC 5.0® were converted by sections into the faces with the largest surface area, so that the software could detect them and perform the meshing. (Figure 5.10)

Figure 5.10 Sectioning of faces with larger surface area

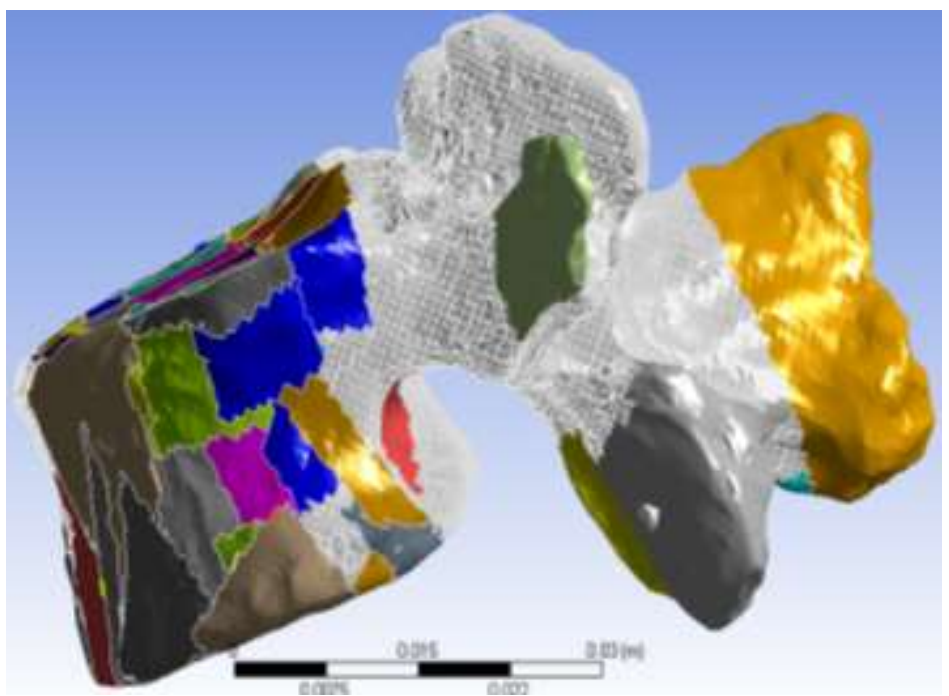


After finishing joining the faces, the parameters that were modified to perform a fine meshing were established, in order to match the geometries of the lumbar vertebrae for greater accuracy in the results. Tables 5.3 and 5.4 show only the parameters that were modified in the software, leaving the others by default for the human vertebral samples and the porcine sample.

Table 5.3 Meshing parameters for human vertebral samples

\begin{tabular}{|c|c|}
\hline \multicolumn{2}{|c|}{ Human vertebral samples } \\
\hline \multicolumn{2}{|l|}{ Defaults } \\
\hline Relevance & 100 \\
\hline \multicolumn{2}{|l|}{ Sizing } \\
\hline Relevance center & Fine \\
\hline Element size & 5.e-004 m \\
\hline Span angle center & Fine \\
\hline Defeature size & $5 . e-004 \mathrm{~m}$ \\
\hline \multicolumn{2}{|l|}{ Quality } \\
\hline Target quality & $5 . \mathrm{e}-004 \mathrm{~m}$ \\
\hline Smoothing & High \\
\hline
\end{tabular}

Table 5.4 Meshing parameters for porcine vertebral specimen

\begin{tabular}{|c|c|}
\hline \multicolumn{2}{|c|}{ Porcine vertebral specimen } \\
\hline \multicolumn{2}{|l|}{ Defaults } \\
\hline Relevance & 50 \\
\hline \multicolumn{2}{|l|}{ Sizing } \\
\hline Relevance center & Medium \\
\hline Transition & Slow \\
\hline Span angle center & Fine \\
\hline Defeature size & $5 . e-004 \mathrm{~m}$ \\
\hline \multicolumn{2}{|l|}{ Quality } \\
\hline Smoothing & High \\
\hline
\end{tabular}

After finishing the meshing of the vertebral samples, the statistics in Table 5.5 were obtained. Figure 5.11 presents a meshed vertebral sample.

Table 5.5 Meshing statistics

\begin{tabular}{|l|c|r|}
\hline \multicolumn{1}{|c}{ Muestra } & Nodes & Elements \\
\hline Porcine lumbar vertebrae & 260796 & 176696 \\
\hline Human lumbar vertebra 4 & 180294 & 113346 \\
\hline Human lumbar vertebra 5 & 175373 & 109781 \\
\hline
\end{tabular}

Figure 5.11 Meshed vertebral specimen

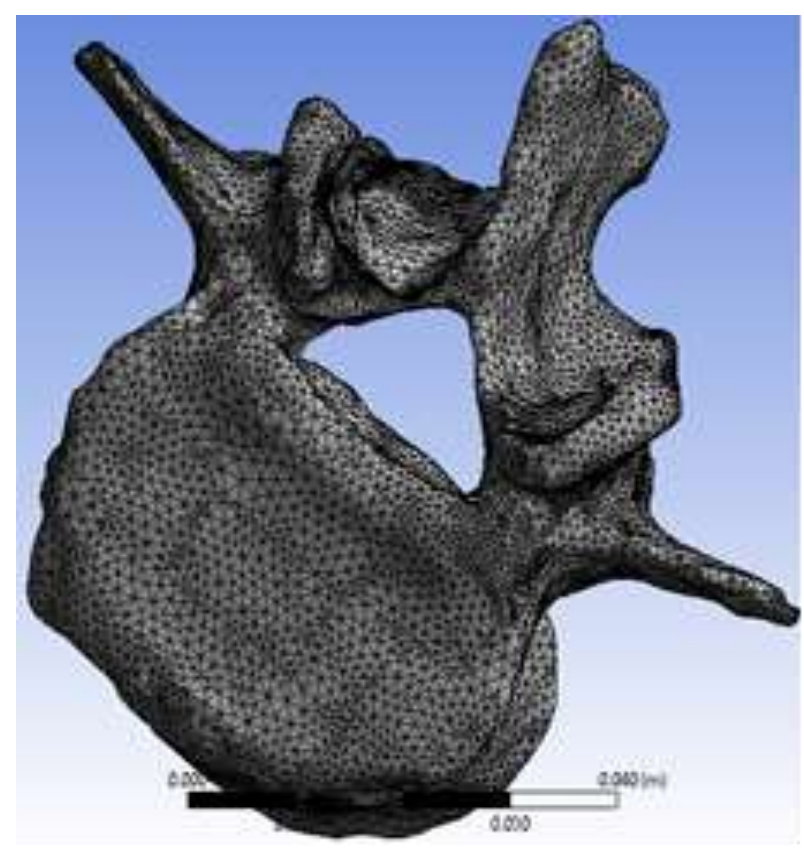


To simulate the compression fracture, the boundary conditions were established with the following data: three loads were applied to each vertebral specimen, two of them according to studies carried out by Nachemson in 1976 [5]; a subject who paradoxically when sitting (sedentary) without dorsal support increases the pressure to $140 \%$ of his body weight. For this case the subject has $70 \mathrm{~kg}$, so a load of $960 \mathrm{~N}$ was used. In which both compression loads are fixed on the upper and lower faces of the vertebral body.

The third load was $8000 \mathrm{~N}$, maximum load at which the lumbar bone fails, taken from the literature "Clinical Biomechanics of the Spine" of 1990 [6], considering that it can be produced by an accident in daily life. This shear load was fixed in the anterior area of the vertebral body.

Figure 5.12 shows in red the areas in which the three loads mentioned above were fixed and in purple the areas that supported these loads. [7]

Figure 5.12 Boundary conditions

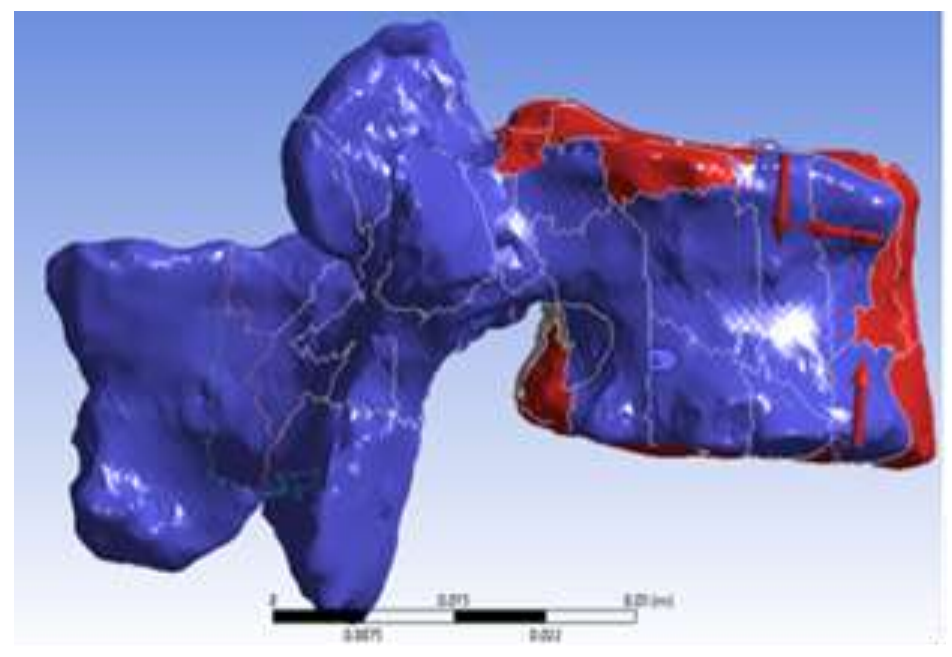

\section{Results}

The results obtained for the porcine vertebral specimen are the maximum and minimum values of stress concentration in the lateral zones, upper and lower faces and anterior zone of the vertebral body, as well as in the vertebral arch zone and in the upper notch. Particularly, the maximum stresses were found in the lateral zone and vertebral arch and the minimum stresses in the spinous process zone. (Figure 12)For the human vertebral specimens, the maximum and minimum values of stress concentration were found in the lateral zones, upper and lower faces and anterior zone of the vertebral body, as well as in the vertebral arch zone and in the upper notch. In particular, maximum stresses were found in the lower face and lateral zone and minimum stresses in the area of the spinous process. (Figures 5.13 and 5.14) The results also show the Von-Mises stress concentration values shown in Table 5.6.

Figure 5.13 Results in porcine lumbar vertebra

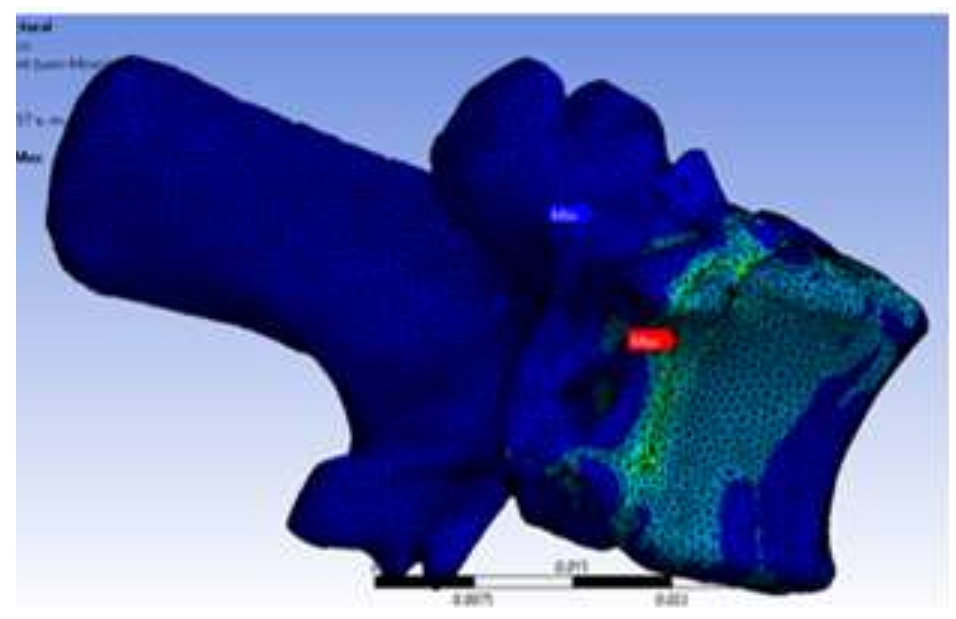


Figure 5.14 Results in human lumbar vertebra 4

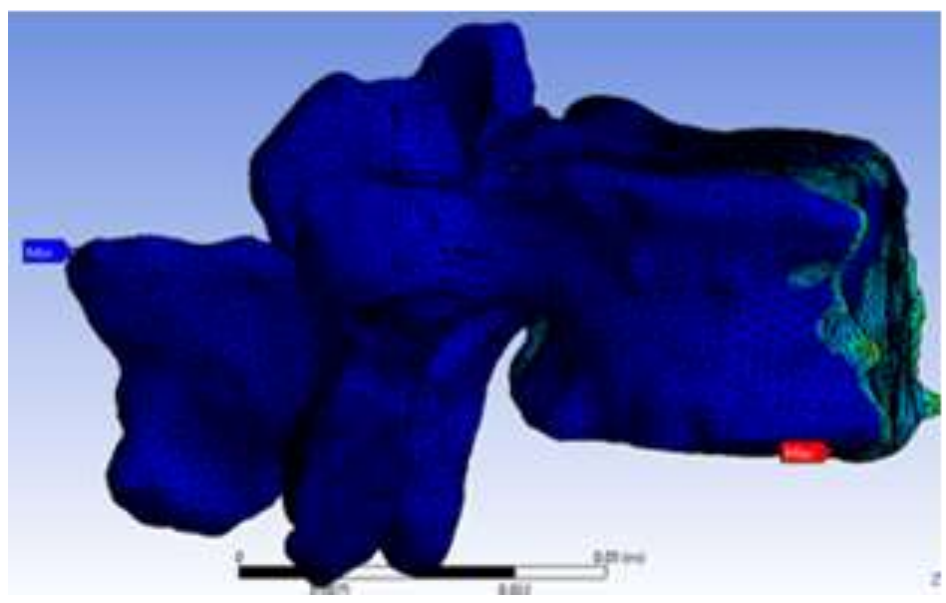

Figure 5.15 Results in human lumbar vertebra 5

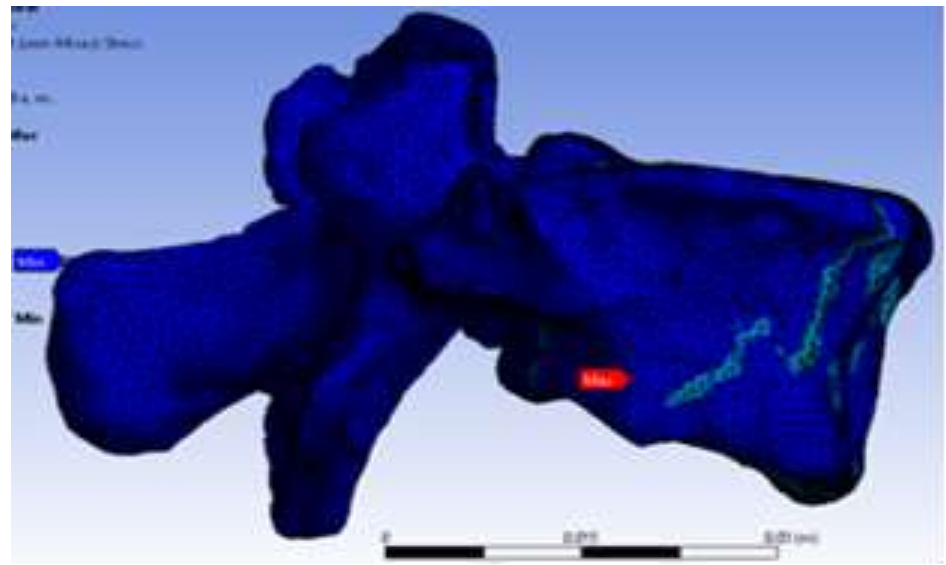

Table 5.6 Von-Mises stress analysis values

\begin{tabular}{|l|r|r|}
\hline \multicolumn{1}{|c|}{ Muestra } & \multicolumn{1}{c}{ Nodes } & Elements \\
\hline Porcine lumbar vertebrae & 101.2 & 0 \\
\hline Human lumbar vertebra 4 & 134.82 & $6.203 \mathrm{e}-10$ \\
\hline Human lumbar vertebra 5 & 189.6 & $2.0437 \mathrm{e}-9$ \\
\hline
\end{tabular}

It should be pointed out that in spite of the porcine lumbar vertebra being geometrically smaller compared to the human lumbar vertebrae, a lower value was obtained in the maximum stress and even remained at zero in the minimum stress.

\section{Conclusions}

In the simulation process, when applying compressive loads of $960 \mathrm{~N}$ and shear loads of $8000 \mathrm{~N}$ distributed in each lumbar vertebra, a maximum Von Mises stress of 134.82 MPa Max and 6.203e-10 MPa Min was obtained for lumbar vertebra 4, 189.6 MPa Max and 2.0437e-9 for lumbar vertebra 5 and 101.2 MPa Max and 0 Min for the porcine lumbar vertebra. The critical points are above $100 \mathrm{MPa}$ for all three cases. The maximum values of stress in the vertebral body and the minimum values in the spinous process were presented.

In the present work it was possible to obtain a numerical model of the porcine lumbar and human lumbar spine L4 and L5. It is suggested to replicate different situations and mechanical conditions to the obtained models for future studies.

3D models of real porcine and human samples (L4 and L5) were obtained with a scanning accuracy of 16 million points in a 1-2 second capture. It is important to have a computer with the capacity to carry out the simulation process. In this case, a computer with an Intel Core i7 processor, 64 GB of internal memory and a storage capacity of $1 \mathrm{~TB}$ was used. 


\section{Acknowledgements}

The authors would like to thank the Unidad ESIME Zacatenco of the Instituto Politécnico Nacional for their kindness and the Unidad de Ciencias de la Salud of the Universidad Veracruzana Campus Poza Rica - Tuxpan for their support.

\section{References}

[1] Vanaclocha, V. (2016). Clínica Neuros. Obtenido de Clínica Neuros: http://neuros.net/es/fracturaaplastamiento_vertebral/

[2] J. Teo, K. S.-H. (2006). "Reationship between CT intensity, micro-architecture and mechanical properties of porcine vertebral cancellous bone". En Clinical Biomechanics (Vol. 21, págs. 235-244).

[3] T. Keavy, T. p. (1997). "Systematic and random errors in compression testing of trabecular bone". En Orthopaedic Research (Vol. 15, págs. 101-110).

[4] J. Wang, M. P.-A. (2000). "Viscoelastic finite-element analysis of a lumbar motion segment in combined compression and sagital flexion". En Spine (Vol. 25, págs. 310-318).

[5] Nachemson A.L (1976). The lumbar spine. An orthopedic challenge. Spine.

[6] A. White III, M. Panjabi (1990). Clinical Biomechanics of the Spine. 2da Ed. Lippincott Williams \& Wilkins. Philadelphia, USA. pp. 2-56.

[7] Blanco Ortiz, K. A. A. (2021). Propuesta de protocolo de ejercicios para fortalecimiento del CORE como medida preventiva en lesiones músculo esqueléticas del raquis lumbar en trabajadores que se encuentran en sedestación con edades comprendidas entre 25 y 30 años por medio de un análisis (Doctoral dissertation). 